\title{
Rainfall climatology, variability, and trends in Veranópolis, Rio Grande do Sul, Brazil
}

\author{
Amanda H. Junges ${ }^{1}$, Carolina Bremm ${ }^{2}$ \& Denise C. Fontana ${ }^{3}$ \\ ${ }^{1}$ Secretaria da Agricultura, Pecuária e Irrigação/Departamento de Diagnóstico e Pesquisa Agropecuária/Centro de Pesquisa Carlos Gayer. Veranópolis, RS, \\ Brasil. E-mail: amanda-junges@seapi.rs.gov.br (Corresponding author) - ORCID 0000-0001-6982-7880 \\ ${ }^{2}$ Secretaria da Agricultura, Pecuária e Irrigação/Departamento de Diagnóstico e Pesquisa Agropecuária/Centro de Pesquisa de Produção Vegetal. Porto \\ Alegre, RS, Brasil. E-mail: carolina-bremm@seapi.rs.gov.br - ORCID: 0000-0002-7612-2771 \\ ${ }^{3}$ Universidade Federal do Rio Grande do Sul/Faculdade de Agronomia/Departamento de Plantas Forrageiras e Agrometeorologia. Porto Alegre, RS, Brasil. \\ E-mail: dfontana@ufrgs.br - ORCID: 0000-0002-2635-6086
}

\begin{abstract}
The objective of this study was to characterize the rainfall climatology in Veranópolis, Rio Grande do Sul, Brazil, through analyses of means, variabilities related to El Niño Southern Oscillation (ENSO), and temporal trends, using a 60-year data series (1956-2015). Descriptive statistics of annual, monthly and seasonal rainfall were used to characterize the rainfall climatology. The differences between seasons, and influence of ENSO were evaluated using analysis of variance and the Duncan's test. Rainfall trends were evaluated by the Mann Kendall test. The local average annual rainfall is $1,683 \mathrm{~mm}$ and the average monthly rainfall is $140 \mathrm{~mm}$, varying from 109 (May) to $182 \mathrm{~mm}$ (September). The annual rainfall has high interannual (standard deviation of $327 \mathrm{~mm})$, monthly $(60-100 \mathrm{~mm})$ and seasonal $(124-183 \mathrm{~mm})$ variabilities, which should be considered in non-irrigated agricultural systems using rainfall as the main source of water supply to plants. Although autumn presents lower average rainfall $(346 \mathrm{~mm})$ than the other seasons, its average percentages were similar to the total annual rainfall (21-28\%), and the rainfalls are well-distributed in the seasons. Differences between ENSO events occurred in the spring; La Niña years showed lower rainfall $(385 \mathrm{~mm})$ than El Niño $(549 \mathrm{~mm})$ and neutral $(481 \mathrm{~mm})$ years. The annual rainfall tended to increase by $6.3 \mathrm{~mm}$ per year $(\mathrm{p}<0.01)$, with increases of $2.5 \mathrm{~mm}$ in spring and $1.9 \mathrm{~mm}$ in winter $(\mathrm{p}<0.10)$ in the period analyzed.
\end{abstract}

Key words: El Niño Southern Oscilation, Mann Kendall test, pluvial precipitation

\section{Climatologia, variabilidade e tendências da precipitação pluvial em Veranópolis, Rio Grande do Sul, Brasil}

RESUMO: Objetivou-se nesse trabalho caracterizar climaticamente a precipitação pluvial, analisar a influência de eventos El Niño Oscilação Sul (ENOS) e a tendência temporal na série de dados 1956-2015 de Veranópolis, Rio Grande do Sul, Brasil. Para caracterização climática foram definidas estatísticas descritivas da precipitação pluvial anual, mensal e estacional. Para identificação de diferenças entre estações e influência de eventos ENOS, os dados foram submetidos à análise de variância e teste de Duncan. Tendências foram avaliadas pelo teste de Mann Kendall. Os resultados indicaram que a precipitação pluvial anual média é de $1.683 \mathrm{~mm}$ e a mensal $140 \mathrm{~mm}$, variando entre 109 (maio) e $182 \mathrm{~mm}$ (setembro). Há elevada variabilidade interanual na precipitação pluvial anual (desvio-padrão de $327 \mathrm{~mm})$, mensal $(60-100 \mathrm{~mm})$ e estacional (124-183 mm), a qual deve ser considerada especialmente em sistemas agrícolas não irrigados nos quais a chuva é o principal mecanismo de aporte de água às plantas. Embora a precipitação pluvial média do outono $(346 \mathrm{~mm})$ seja inferior à das demais estações, os percentuais médios em relação ao total anual são semelhantes (21-28\%) e a chuva é bem distribuída nas estações. Diferenças entre eventos ENOS ocorreram na primavera, sendo que chove menos em eventos La Niña $(385 \mathrm{~mm})$ do que em El Niño $(549 \mathrm{~mm})$ e neutros $(481 \mathrm{~mm})$. Há tendência climática de aumento da precipitação pluvial anual em $6,3 \mathrm{~mm}$ ao ano $(\mathrm{p}<0,01)$, assim como na primavera $(2,5 \mathrm{~mm})$ e inverno $(1,9 \mathrm{~mm})(\mathrm{p}<0,10)$ na série analisada.

Palavras-chave: El Niño Oscilação Sul, teste de Mann Kendall, chuva

Ref. 192653 - Received 09 Mar, 2018 • Accepted 30 Nov, 2018 • Published 30 Jan, 2019 


\section{INTRODUCTION}

Agriculture is the most dependent economic activity on weather and climate conditions, thus, climate characterization is essential to reduce risks in agricultural production. Long-term historical data series, with more than 30 years of meteorological observations, can define the local climate by expressing averages of climatic variables, allowing the evaluation of interannual variability, trends, and climate changes. Most climate change studies have a global scale, and the regionalization of their projections can be misleading. Therefore, regional studies are essential to characterize shortterm climatic variability and analyze local trends and possible changes (Baethgen, 2010).

Studies have shown tendencies of increase in annual rainfall for the state of Rio Grande do Sul, Brazil. Cera \& Ferraz (2015) found increases in rainfall in large part of the state using a 25year data series (1982-2006). Cordeiro (2010) found increases in total annual rainfall using averages of 14 meteorological stations in different ecoclimatic regions of the state of a 60 -year data series (1950-2009). Sansigolo \& Kayano (2010) found a trend of increase in annual rainfall, especially for summers, using a 94-year data series (1913-2006) of six municipalities of the state.

Rainfall is one of the main criteria for climate risk zoning and for definition of sowing times of annual grain crops in Rio Grande do Sul. Moreover, it is the main source of water supply to plants in non-irrigated systems, and affects the development of natural and planted pastures, and perennial crops such as fruit trees. Changes in the rainfall regime of this state have been associated with ENSO (El Niño Southern Oscillation) events, which is reported as the greatest source of climatic variability in seasonal and interannual scales (Berlato \& Fontana, 2003; Britto et al., 2008; Matzenauer et al., 2017). Information about the ENSO influence on rainfall is therefore essential for the development of agricultural strategies in Rio Grande do Sul (Matzenauer et al., 2017).

Rainfall is one of the most important meteorological variables for agricultural production, and long-term historical data series are essential for the understanding of the climate and to define local agricultural strategies. Thus, the objective of this study was to characterize the rainfall climatology in Veranópolis, Rio Grande do Sul, Brazil, through analyses of means, variabilities related to El Niño Southern Oscillation (ENSO), and temporal trends, using a 60-year data series (1956-2015).

\section{Material AND Methods}

Monthly rainfall data from a 60-year data series (19562015) of the meteorological station of the Carlos Gayer

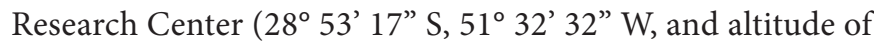
$707 \mathrm{~m}$ ) in Veranópolis, were used. This municipality is in the Encosta Superior da Serra do Nordeste an ecophysiographic region known as Serra Gaúcha in the state of Rio Grande do Sul (RS), Brazil. According to the Köppen classification, the climate of this region is $\mathrm{Cfb}$, i.e., it has a temperate climate, without dry season, and average temperature in the hottest month below $22^{\circ} \mathrm{C}$ (Alvares et al., 2013),

The rainfall regime was characterized based on descriptive statistics, mean, median, standard deviation (SD), and amplitudes of monthly and annual rainfall using a 60-year data series (1956-2015) and the climatological normal of 19611990. Descriptive statistics, and frequency distribution were performed for annual and seasonal rainfall data. The periods of the seasons were defined according to Folhes \& Fish (2006) and Berlato \& Cordeiro (2017), considering the sum of the rainfall occurred in March-April-May (autumn), June-JulyAugust (winter), September-October-November (spring) and December-January-February (summer).

These seasons of the year were also used to describe El Niño Southern Oscillation (ENSO) events, according to the classification of the National Oceanic and Atmospheric Administration (NOAA). This classification is based on a deviation of $\pm 0.5^{\circ} \mathrm{C}$ from the average of Sea Surface Temperature (SST) of these three-month periods in the Niño 3.4 region for at least five months.

The influence of ENSO events on total accumulated rainfall was evaluated by subjecting the data to analysis of variance and, when significant ( $\mathrm{p}<0.05)$, to the Duncan test. The annual and seasonal rainfall trends were evaluated with the Mann Kendall's non-parametric statistical test, considering significant temporal trends with $\mathrm{p}<0.10$. The Mann Kendall test, which is recommended by the World Meteorological Organization (WMO), was used, since the succession of values occurs independently and the probability distribution remains the same in the case of stability of a time series (Back, 2001).

\section{Results AND Discussion}

The mean total annual rainfall in Veranópolis according to the 60-year data series analyzed (1956-2015) is $1,683 \mathrm{~mm}$, and according to the climatological normal of $1961-1990$ it is $1,636 \mathrm{~mm}$ (Figure 1A). These results were similar to the climatological normal 1961-1990 of Bento Gonçalves (1,684 mm), and Caxias do Sul $(1,823 \mathrm{~mm})$ (INMET, 2018), in the same ecophysiographic region. The average annual rainfall of 1956-2015 was higher than the climatological normal of 1961-1990 (Figure 1A), especially due to the average annual rainfall of 2002, 2009 and 2015 , in which the total annual rainfall were above 2,010 $\mathrm{mm}$ (equivalent to the average $+1 \mathrm{SD}$ of the series) (Figure $1 \mathrm{~A}$ ). The highest average annual rainfall was found in $2015(2,610 \mathrm{~mm})$, and the minimum in 1962 (878 $\mathrm{mm}$ ) (Figure 1A).

The mean annual rainfall of the study region was similar to that found by Britto et al. (2008). Therefore, the annual rainfall in the northern Rio Grande do Sul (north of latitude $30^{\circ} \mathrm{S}$ ), which includes the Encosta Superior da Serra do Nordeste, is higher than $1,500 \mathrm{~mm}$, and it is less than $1,500 \mathrm{~mm}$ in the south of the state. Rainfall in the South of Brazil is influenced by frontal systems; moreover, this region is subject to tropical systems in the summer, which cause intense rains. These rains, combined with the local orography, explains the high total annual rainfall that characterizes the north of Rio Grande do Sul (Britto et al., 2008). 



Figure 1. Box plot diagram of annual rainfall (A), and monthly average rainfall in the data series 1956-2015 and in the climatological normal of 1961-1990 (B); and box plot diagram of monthly rainfall in the data series 1956-2015 (C)

The annual rainfall in the 1956-2015 data series and in the climatological normal had similar variability, with means higher than the medians, and standard deviations above 300 $\mathrm{mm}$ (Figure 1A). The similar frequency between rainfall ranges from $1,400-1,600$ to $1,800-2,000 \mathrm{~mm}$ (Figure $2 \mathrm{~A}$ ) confirmed the interannual variability of the total annual rainfall, with the mean $(1,683 \mathrm{~mm})$ not in the highest frequency range $(1,400$ to $1,600 \mathrm{~mm}$ ) (15 years), followed by $1,800-2,000 \mathrm{~mm}$ (12 years) (Figure 2A).

Evaluations of average annual rainfall, and data fluctuations around the mean provide information about water availability to agricultural systems. Rainfall is the main water source for non-irrigated agricultural systems, affecting soil water storage and, consequently, water absorption capacity by the roots, and plant water status (Sentelhas \& Monteiro, 2009).

Considering the climatological normal of 1961-1990, the lowest monthly average rainfall in Veranópolis is in April (102 mm) and May $(103 \mathrm{~mm})$ (Figure 1B), presenting similar results to the means found in Bento Gonçalves (April, $93 \mathrm{~mm}$ ), and Caxias do Sul (April, $100 \mathrm{~mm}$ ) (INMET, 2018). September has the highest average rainfall in the climatological normal of 1961-1990 (173 mm) and in the 1956-2015 data series (181 mm) (Figure 1B). September was also point out as the month with the highest average rainfall by Czermainski \& Zat (2011) in Bento Gonçalves, with $179 \mathrm{~mm}$ in the 1961-2010 data series, although in the climatological normal the highest average rainfall was in August (174 mm) (INMET, 2018).

The monthly average rainfall in 1956-2015 data series is $140 \mathrm{~mm}$, ranging from $109 \mathrm{~mm}$ in May to $181 \mathrm{~mm}$ in September (Figure 1B). This result confirms the Köppen climatic classification, showing no defined dry season, i.e., no month with mean rainfall of less than $60 \mathrm{~mm}$ (Figure
1B). The monthly data presented high interannual variability, with a mean standard deviation of $75 \mathrm{~mm}$, from $60 \mathrm{~mm}$ (February and March) to $100 \mathrm{~mm}$ in September (Figure 1C). Thus, September can be characterized as the month with the highest average rainfall, the greatest interannual variability, and greatest difference between mean and median rainfall (Figure 1C), indicating an asymmetric distribution of the data. The maximum monthly rainfall in the data series analyzed $(500 \mathrm{~mm}$ in 2009) also occurred in September.

The mean rainfall in autumn $(346 \mathrm{~mm})$ was lower than in winter $(439 \mathrm{~mm})$, spring $(480 \mathrm{~mm})$, and summer $(415 \mathrm{~mm})$ (Table 1). Spring had the highest accumulated rainfall, although it was statistically similar to the average rainfall in winter (Table 1). Summer had mean rainfall lower than spring, and no different than winter (Table 1).

The contributions of the seasons to the annual rainfall was $21 \%$ (autumn), 26\% (winter), 28\% (spring), and 25\% (summer), similar to those described for Rio Grande do Sul by Berlato \& Fontana (2003).

The accumulated rainfall in the spring had high interannual variability, with higher standard deviation $(183 \mathrm{~mm})$ than the other seasons (Figure 2B). Although the mean accumulated rainfall $(480 \mathrm{~mm})$ was found in the highest range, from 400 to $500 \mathrm{~mm}$ (13 years) (Figure 2B), spring was characterized by similar frequencies in the ranges (Figure 2B). The lowest accumulated rainfall in spring were $203 \mathrm{~mm}$ (1971) and $210 \mathrm{~mm}$ (1962), and the highest were $857 \mathrm{~mm}$ (1961), $941 \mathrm{~mm}$ (2009), and $945 \mathrm{~mm}$ (2015).

ENSO events influence climatic anomalies of rainfall in Rio Grande do Sul (Britto et al., 2008); years of El Niño had above average rainfall, especially in spring and early summer (October to December) (Berlato \& Fontana, 2003), as also

Table 1. Mean accumulated rainfall in the spring, summer, autumn, and winter in a 60-year data series (1956-2015), with years classified as El Niño, La Niña, and neutral

\begin{tabular}{|c|c|c|c|c|c|c|c|c|c|c|c|c|}
\hline \multirow{4}{*}{ ENSO events } & \multicolumn{12}{|c|}{ Accumulated rainfall (mm) } \\
\hline & \multicolumn{3}{|c|}{$\begin{array}{c}\text { Autumn } \\
\text { March to May }\end{array}$} & \multicolumn{3}{|c|}{$\begin{array}{c}\text { Winter } \\
\text { Jun to August }\end{array}$} & \multicolumn{3}{|c|}{$\begin{array}{c}\text { Spring } \\
\text { September to November }\end{array}$} & \multicolumn{3}{|c|}{$\begin{array}{c}\text { Summer } \\
\text { December to February }\end{array}$} \\
\hline & \multicolumn{2}{|c|}{ Years } & \multirow{2}{*}{ Mean } & \multicolumn{2}{|c|}{ Years } & \multirow{2}{*}{ Mean } & \multicolumn{2}{|c|}{ Years } & \multirow{2}{*}{ Mean } & \multicolumn{2}{|c|}{ Years } & \multirow{2}{*}{ Mean } \\
\hline & $\mathrm{N}^{\circ}$ & $\%$ & & $\mathrm{~N}^{\circ}$ & $\%$ & & $\mathrm{~N}^{\circ}$ & $\%$ & & $\mathrm{~N}^{\circ}$ & $\%$ & \\
\hline Neutral & 37 & 62 & $324 a$ & 35 & 59 & $440 \mathrm{a}$ & 25 & 42 & $481 a b$ & 22 & 37 & $391 \mathrm{a}$ \\
\hline El Niño & 12 & 20 & $395 \mathrm{a}$ & 14 & 23 & $484 \mathrm{a}$ & 20 & 33 & $549 a$ & 21 & 35 & $431 \mathrm{a}$ \\
\hline La Niña & 11 & 18 & $367 \mathrm{a}$ & 11 & 18 & $376 \mathrm{a}$ & 15 & 25 & $385 b$ & 17 & 28 & $420 \mathrm{a}$ \\
\hline
\end{tabular}

Means followed by uppercase letters in the rows or lowercase letters in the columns do not differ by the Duncan test $(p<0.05)$ 

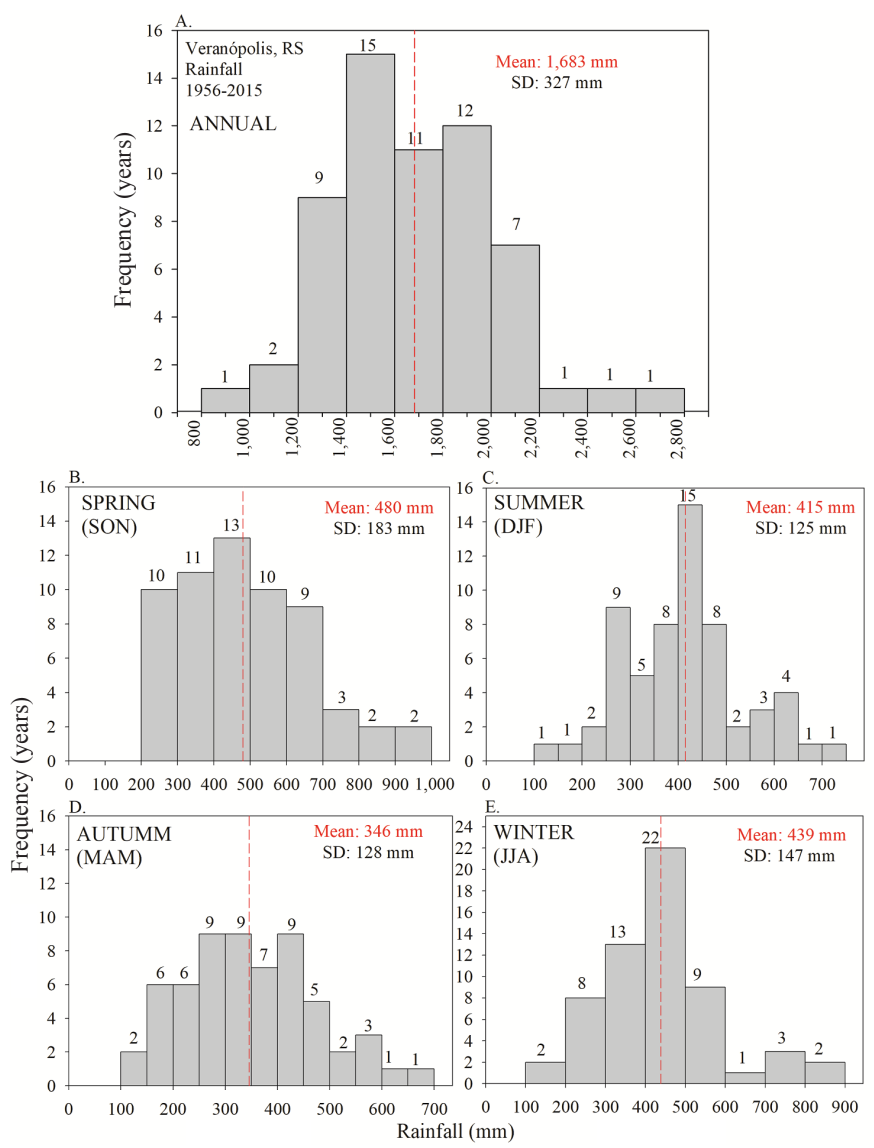

Figure 2. Mean, standard deviation, and distribution frequency of annual rainfall $(A)$ and rainfall in spring $(B)$, summer $(C)$, autumn (D), and winter (E) using a 60-year data series (1956-2015) found in the present study. Spring had different accumulated rainfall depending on ENSO events (Table 1), with averages in La Niña years lower than in El Niño years; and neutral years not differed from the others. Matzenauer et al. (2017) also found spring as the most affected season by ENSO events in Rio Grande do Sul, presenting the standard response, i.e., more rainfall in El Niño years, less in La Niña years, and intermediate in neutral years.

The maximum accumulated rainfalls were found in the springs of 2009 and 2015 in the analyzed data series; it may be associated with the occurrence of El Niño (Figure 3A). The spring of 2009 had already been identified by Cordeiro (2010) as the rainiest season in the 1950-2009 data series in Rio Grande do Sul. In Veranópolis, 28 of the analyzed years (47\%) had positive rainfall deviations in the spring, i.e., higher when compared to the historical average. The deviations in nine of the evaluated years were greater than $663 \mathrm{~mm}($ mean+1SD) (Figure 3A), and five of these had springs influenced by $\mathrm{El}$ Niño events (Figure 3A).

The number of years with negative deviations of rainfall (32; $53 \%$ ) in spring was higher than those with positive deviations. Deviations below 297 mm (mean-1SD) occurred in 10 years; five of them with low rainfall associated with La Niña events (Figure 3A). Low accumulated rainfalls in the spring, such as those occurring due to La Niña events affect positively the yield of winter grains crops (Cunha et al., 2001).

Summer had mean accumulated rainfall of $415 \mathrm{~mm}$, and lower standard deviation $(125 \mathrm{~mm})$ than the other seasons (Figure $2 \mathrm{C}$ ). The mean was in the most frequent (23 years)

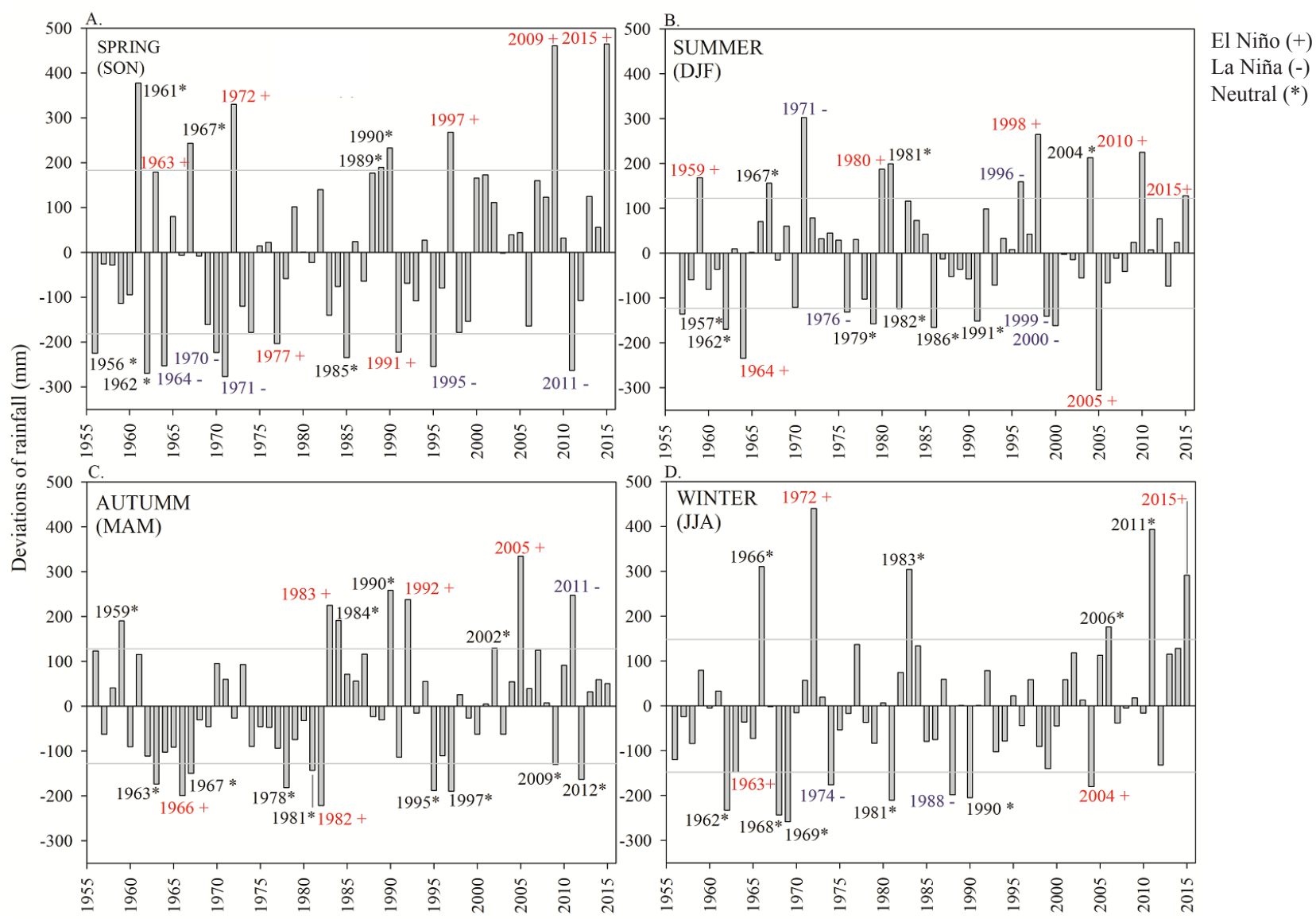

Figure 3. Deviations of rainfall in spring (A), summer (B), autumn (C), and winter (D) in a 60-year data series (1956-2015), with identification of ENSO events (El Niño, La Niña, and neutral years) in seasons with deviations (mean \pm 1 standard deviation) 
range (400 to $500 \mathrm{~mm}$ ) (Figure 2C). The lowest accumulated rainfall in the summer $(110 \mathrm{~mm})$ was in 2005 , followed by $1962(181 \mathrm{~mm})$. Negative deviations of rainfall occurred in 29 of the analyzed years (48\%), 11 of them had accumulated rainfall of less than $290 \mathrm{~mm}$ (mean-1SD) and, in 2005, lower than $169 \mathrm{~mm}$ (mean-2SD).

The accumulated rainfall in summer in El Niño years did not differ from those in La Niña years (Table 1). Although no difference in accumulated rainfall is found, the interannual variability of rainfall in summer and occurrence of droughts, even when not associated with ENSO events, have effect on the yield of the main agricultural crops in the spring-summer period in Rio Grande do Sul (Berlato \& Fontana, 2003).

Six of the 11 summers with the lowest accumulated rainfall were in neutral, two in El Niño, and three in La Niña years (Figure 3B), indicating that less accumulated rainfall in summer occurs more frequently in neutral years. Similarly, Matzenauer at al. (2017) evaluated the rainfall regime of the state of Rio Grande do Sul using a 50-year data series (19612010) from 28 meteorological stations and concluded that in most places it rains less in the summer in neutral years. In Veranópolis, ten summers had accumulated rainfall exceeding $540 \mathrm{~mm}$ (mean+1SD), five of them in El Niño, two in La Niña, and three in neutral years. The summers of $1971(718 \mathrm{~mm})$, and $1998(680 \mathrm{~mm})$, had total accumulated rainfall greater than $665 \mathrm{~mm}$ (mean +2SD) (Figure 3B).

These results are important for the planning of agricultural crops, since rainfalls in summer months affect the yield of the main spring-summer grain crops in Rio Grande do Sul (Matzenauer et al., 2017). Rainfall characterization in studies that use long-term historical data series is important for non-irrigated agriculture, assisting in the planning of management practices that improve the use of natural rainfall. This is especially important for regions where the rainfall is well distributed in the seasons but, in general, the average rainfall does not exceed the optimal water demands of springsummer crops due to higher evapotranspiration demand of the atmosphere in summer (Berlato \& Fontana, 2003). Thus, planning agricultural activities in the study region should consider that the adequate supply of water for the springsummer crops is dependent on interannual rainfall variability, or irrigation.

Autumn had the lowest average accumulated rainfall $(346 \mathrm{~mm})$, and similar standard deviation $(128 \mathrm{~mm})$ to the summer (Figure 2D). The rainfall distribution frequency in autumn was similar between the ranges (Figure 2D), and the lowest accumulated rainfall were $125 \mathrm{~mm}$ (1982), and $158 \mathrm{~mm}$ (1995), and the highest was $681 \mathrm{~mm}$ (2005). Negative deviations in the data series for rainfall in autumn occurred in 32 years (53\%); 10 years had deviations lower than $221 \mathrm{~mm}$ (mean-1SD), and eight of them were in neutral years (Figure 3C). Positive deviations for rainfall over $474 \mathrm{~mm}$ (mean+1SD) occurred in eight years, four of them in neutral, three in El Niño, and one in La Niña year (Figure 3C).

The most frequent (22 years) accumulated rainfall range in winter was 400 to $500 \mathrm{~mm}$; the mean in the data series analyzed was $439 \mathrm{~mm}$ (Figure 2E). The standard deviation of $147 \mathrm{~mm}$ indicated that winter has the second highest rainfall variability
(Figure 2E). Nine years were characterized by winter rainfall less than $292 \mathrm{~mm}$ (mean-1SD), five of them in neutral, two in El Niño, and two in La Niña years (Figure 3D). Six years had positive rainfall deviation, with rainfall above $586 \mathrm{~mm}$ $($ mean+1SD), two of them in El Niño, and 4 in neutral years. The accumulated rainfall in the winters of $1966(749 \mathrm{~mm})$, $1972(879 \mathrm{~mm}), 1983(743 \mathrm{~mm})$ and $2011(832 \mathrm{~mm})$ were above $733 \mathrm{~mm}($ mean+2SD) (Figure 3D).

The mean accumulated rainfall in autumn and winter in neutral, El Niño, and La Niña years did not differ (Table 1), indicating that rainfall variability in these seasons is not due to ENSO events. The main periods influenced by El Niño in Rio Grande do Sul is spring and early summer, especially October and November (Berlato \& Fontana, 2003; Matzenauer et al., 2017).

The Mann Kendall test indicated an increase in annual rainfall in Veranópolis of $6.34 \mathrm{~mm}$ per year $(\mathrm{p}<0.01)$ (Figure 4A). Haylock et al. (2006) found increasing annual rainfall trend in a study involving 54 South American meteorological stations using a 41-year data series (1960-2000); Berlato \& Cordeiro (2017) found an increase in annual rainfall of approximately $10 \%$ in almost all state of Rio Grande do Sul using a 60-year data series (1950-2009) when compared to the climatological normal of 1950-1979; and Cordeiro (2010) found a linear increase in annual rainfall in Rio Grande do Sul of approximately $4 \mathrm{~mm}$ per year, similar to that reported by Cunha et al. (2007) for Passo Fundo using a 90-year data series (1917-2006).

Veranópolis presented a trend of increasing accumulated rainfall in spring $(+2.54 \mathrm{~mm})$ (Figure $4 \mathrm{~B})$ and winter $(+1.86 \mathrm{~mm})$ (Figure $4 \mathrm{C})(\mathrm{p}<0.10)$. These trends were influenced by the springs of 2009 and 2015, which had accumulated rainfalls above $900 \mathrm{~mm}$. Cordeiro (2010) also found a linear trend of


ns - Not significant

Figure 4. Trends of annual rainfall (A), and rainfall in spring (B), winter $(C)$, autumn $(D)$ and summer $(E)$, considering the 19562015 data series, estimated by the Mann Kendall test 
increase in accumulated rainfall in the spring for the state, but without a significant trend for the winter, which is possibly due to the data series used, which ended in 2009. The results found for $2011(832 \mathrm{~mm})$ and $2015(730 \mathrm{~mm})$ contributed to the trend in the winter found in Veranópolis (Figure 4C). Increases in rainfall in winter can delay the implementation of winter cereal crops, and denote the importance of establishing cover crops to reduce soil losses and water runoff.

Rainfall increases in the spring affect negatively the final yield and quality of winter grain crops and may damage the flowering of temperate fruit trees. Intensive, frequent rainfalls in late spring, coinciding with grain filling, maturation, and harvesting, decrease grain yield and quality due to lower starch deposition and preharvest germination (Cunha et al., 2001). The flowering of vines is hindered by high air humidity, and rainy periods, making it difficult the pollination and fixation of fruits, causing formation of bunches with fewer berries (Mandelli et al., 2009). Nachtigall et al. (2009) report that excessive rainfall is harmful to apple trees during flowering and early vegetative development stages by reducing the action of pollinating insects and increasing the incidence of foliar diseases.

The results indicated no trend in accumulated rainfall in autumn $(+1.55 \mathrm{~mm})$ (Figure 4D) and summer $(+0.32 \mathrm{~mm})$ (Figure $4 \mathrm{E})$ in Veranópolis, which confirms the results of Berlato \& Cordeiro (2017), who analyzed the spatial distribution of the rainfall trend in Rio Grande do Sul using a 60-year data series (1950-2009) and found that the Encosta Superior da Serra do Nordeste presents not significant trend in these seasons, unlike the other regions of the state.

The rainfall trends of Veranópolis are consistent with other studies carried out with long-term meteorological data, and emphasize the importance of local studies to identify changes in climatic patterns at regional scales. This study aimed to define the regional climatology and quantify the current variability, since such variability (short-term) has the greatest impact on the agricultural activities of a small region. According to Berlato \& Cordeiro (2017), the rainfall variability and trends in Rio Grande do Sul are largely associated with anomalies in the equatorial Pacific sea surface temperature (SST) (ENSO), however, the rainfall in the state of Rio Grande do Sul are also influenced by the Pacific Decadal Oscillation, and South Atlantic SST.

Long-term historical data series from meteorological stations are not found in all municipalities, thus, the results of this work contribute to the climatic characterization and definition of trends for the region of the Encosta Superior da Serra do Nordeste, known as Serra Gaúcha, in Rio Grande do Sul, Brazil.

\section{Conclusions}

1. The mean annual rainfall in Veranópolis, in the state of Rio Grande do Sul, Brazil, is greater than 1,500 $\mathrm{mm}$. The region presents no defined dry season, but has high interannual variability of annual, monthly, and seasonal rainfall.

2. The accumulated rainfall in autumn is lower than that of other seasons. Spring has the highest accumulated rainfall, but with similar means to the winter. Summer has less rainfall than spring, but with no differences from the winter.

3. Differences in accumulated rainfall in El Niño, La Niña, and neutral years occur only in spring, with less rainfall in La Niña than in El Niño years; and neutral years do not differ from El Niño and La Niña years.

4. Veranópolis presents a tendency of increase in annual rainfall, and in rainfall in the spring and winter, when considering the 60-year data series from 1956 to 2015.

\section{Literature Cited}

Alvares, C. A.; Stape, J. L.; Sentelhas, P. C.; Gonçalves, J. L. de M.; Sparovek, G. Köppen's climate classification map for Brazil. Meteorologische Zeitschrift, v.22, p.711-728, 2013. https://doi. org/10.1127/0941-2948/2013/0507

Back, A. J. Aplicação de análise estatística para identificação de tendências climáticas. Pesquisa Agropecuária Brasileira, v.36, p.717726, 2001. https://doi.org/10.1590/S0100-204X2001000500001

Baethgen, W. E. Climate risk management for adaptation to climate variability and change. Crop Science, v.50, p.70-76. 2010. https:// doi.org/10.2135/cropsci2009.09.0526

Berlato, M. A.; Cordeiro, A. P. A. Sinais de mudanças climáticas globais e regionais, projeções para o século XXI e as tendências observadas no Rio Grande do Sul: Uma revisão. Agrometeoros, v.25, p.273-302, 2017.

Berlato, M. A.; Fontana, D. C. El Niño e La Niña: Impactos no clima, na vegetação e na agricultura do Rio Grande do Sul. Porto Alegre: UFRGS, 2003. 110p.

Britto, F. P.; Barletta, R.; Mendonça, M. Variabilidade espacial e temporal da precipitação pluvial no Rio Grande do Sul: Influência do fenômeno El Niño Oscilação Sul. Revista Brasileira de Climatologia, v.3, p.1-12, 2008.

Cera, J. C.; Feraz, S. E. T. Variações climáticas na precipitação no sul do Brasil no clima presente e futuro. Revista Brasileira de Meteorologia, v.30, p.81-88, 2015. https://doi.org/10.1590/0102778620130588

Cordeiro, A. P. A. Tendências climáticas das variáveis meteorológicas originais, estimadas e das derivadas do balanço hídrico seriado do Rio Grande do Sul. Porto Alegre: UFRGS, 2010. 273p. Dissertação Mestrado

Cunha, G. R.; Dalmago, G. A.; Nicolau, M.; Pasinato, A. Análise de tendências na temperatura do ar e na precipitação pluvial na região de Passo Fundo, RS. Passo Fundo: Embrapa Trigo, 2007. 15p. Boletim, 48

Cunha, G. R.; Haas, J. C.; Maluf, J. R. T.; Caramori, P. H.; Assad, E. D.; Braga, H. J.; Zullo Júnior, J.; Lazzarotto, C.; Gonçalves, S.; Wrege, M.; Brunetta, D.; Dotto, S. R.; Pinto, H. S.; Brunini, O.; Thomé, V. M. R.; Zampieri, S. L.; Pasinato, A.; Pimentel, M. B. M.; Pandolfo, C. Zoneamento agrícola e época de semeadura para o trigo no Brasil. Revista Brasileira de Agrometeorologia, v.9, p.400-414, 2001.

Czermainski, A. B. C.; Zat, D. A. 50 anos de informações meteorológicas de Bento Gonçalves. Bento Gonçalves: Embrapa Uva e Vinho, 2011. 16p. Comunicado Técnico, 113

Folhes, M. T.; Fisch, G. Caracterização climática e estudo de tendências nas séries temporais de temperatura do ar e precipitação em Taubaté (SP). Ambiente \& Água, v.1, p.61-71, 2006. https://doi. org/10.4136/ambi-agua.6 
Haylock, M. R.; Peterson, T.; Sousa, J. R. de A.; Alves, L. M.; Ambrizzi, T.; Baez, J.; Brito, J. I. B.; Barros, V. R.; Berlato, M. A.; Bidegain, M.; Coronel, G.; Corradi, V.; Grimm, A. M.; Santos, R. J.; Karoly, D.; Marengo, J. A.; Marino, M. B.; Meira, P. R.; Miranda, G. C.; Molion, L.; Muncunil, D. F.; Nechet, D.; Ontaneda, G.; Quintana, J.; Ramirez, E.; Rebello, E.; Rusticucci, M.; Santos, J. L.; Varillas, I. T.; Villanueva, J. G.; Vincent, L.; Yumico, M. Trends in total and extreme South American rainfall in 1960-2000 and links with sea surface temperature. Journal of Climate, v.19, p.1490-1521, 2006. https://doi.org/10.1175/JCLI3695.1

INMET - Instituto Nacional de Meteorologia. Normais climatológicas do Brasil 1961-1990. Disponível em: <http://www.inmet.gov.br/ portal/index.php? $\mathrm{r}=$ clima/normaisclimatologicas $>$. Acesso em: Jan. 2018.
Mandelli, F.; Miele, A.; Tonietto, J. Uva em clima temperado. In: Monteiro, J. E. B. A. (org.). Agrometeorologia dos cultivos. Brasília: INMET, 2009. Cap.29, p.503-515.

Matzenauer, R.; Radin, B.; Maluf, J. R. T. O fenômeno ENOS e o regime de chuvas no Rio Grande do Sul. Agrometeoros, v.5, p.323-331, 2017.

Nachtigall, G. R.; Fioravanço, J. C.; Hoffmann, A. Macieira. In: Monteiro, J. E. B. A. (org.). Agrometeorologia dos cultivos. Brasília: INMET, 2009. Cap.25, p.449-464.

Sansigolo, C. A.; Kayano, M. T. Trends of seasonal maximum and minimum temperatures and precipitation in Southern Brazil for the 1913-2006 period. Theoretical and Applied Climatology, v.101, p.209-216, 2010. https://doi.org/10.1007/s00704-010-0270-2

Sentelhas, P. C.; Monteiro, J. E. B. A. Agrometeorologia dos cultivos. In: Monteiro, J. E. B. A. (org.). Agrometeorologia dos cultivos. Brasília: INMET, 2009. Cap.1, p.3-12. 